University of Nebraska - Lincoln

DigitalCommons@University of Nebraska - Lincoln

Publications from USDA-ARS / UNL Faculty

U.S. Department of Agriculture: Agricultural

Research Service, Lincoln, Nebraska

2004

\title{
Plasma clearance and tissue distribution of radiolabeled leptin in the chicken
}

John P. McMurtry

United States Department of Agriculture-Agricultural Research Service, mcmurtry@anri.barc.usda.gov

Christopher M. Ashwell

United States Department of Agriculture- Agricultural Research Service

Donna M. Brocht

United States Department of Agriculture- Agricultural Research Service

Thomas J. Caperna

United States Department of Agriculture- Agricultural Research Service

Follow this and additional works at: https://digitalcommons.unl.edu/usdaarsfacpub

Part of the Agricultural Science Commons

McMurtry, John P.; Ashwell, Christopher M.; Brocht, Donna M.; and Caperna, Thomas J., "Plasma clearance and tissue distribution of radiolabeled leptin in the chicken" (2004). Publications from USDAARS / UNL Faculty. 683.

https://digitalcommons.unl.edu/usdaarsfacpub/683

This Article is brought to you for free and open access by the U.S. Department of Agriculture: Agricultural Research Service, Lincoln, Nebraska at DigitalCommons@University of Nebraska - Lincoln. It has been accepted for inclusion in Publications from USDA-ARS / UNL Faculty by an authorized administrator of DigitalCommons@University of Nebraska - Lincoln. 


\title{
Plasma clearance and tissue distribution of radiolabeled leptin in the chicken
}

\author{
John P. McMurtry*, Christopher M. Ashwell, Donna M. Brocht, Thomas J. Caperna \\ Growth Biology Laboratory, U.S. Department of Agriculture, Agricultural Research Service, GBL, ANRI, Bldg. 200, Rm. 217, BARC-East, \\ 10300 Baltimore Avenue, Beltsville, MD 20705-2350, USA
}

Received 18 November 2003; received in revised form 14 February 2004; accepted 16 February 2004

\begin{abstract}
Leptin is an adipose and liver tissue-derived secreted protein in chickens that has been implicated in the regulation of food intake and whole-body energy balance. In this study, the metabolic clearance and tissue uptake of leptin were examined in the chicken (Gallus gallus). Four-week-old broiler males were infused with ${ }^{125}$ I-labeled mouse leptin. Chromatography of radiolabeled leptin in plasma produced two peaks, one at $16 \mathrm{kDa}$ (free leptin) and a free iodine peak. No leptin binding protein in blood was detected. Leptin was cleared with a half-life estimate of $23 \mathrm{~min}$. In order to investigate the tissue distribution and uptake of radiolabeled leptin, multiple tissues were removed from infused birds at 15 and 240 min post-infusion, and trichloroacetic acid (TCA)-precipitable radioactivity was determined. The amounts of radioactivity at 15 min post-infusion in the tissues in rank order were: kidney, testis, lung, spleen, heart, liver, small and large intestine, gizzard, pancreas, bursa, leg and breast muscle, adrenals, and brain. A slightly different pattern of distribution was observed at 240 min postinfusion. We conclude from these studies that unlike mammals, no circulating leptin binding protein is present in chickens. Leptin is metabolized and cleared very rapidly from blood by the kidney.
\end{abstract}

Published by Elsevier Inc.

Keywords: Binding proteins; Food intake; Hormone; Receptor

\section{Introduction}

Since its initial discovery in 1994, the biology of leptin has been most extensively studied in mammals (Barb et al., 2001; Chilliard et al., 2001; Attele et al., 2002; Blevins et al., 2002; Margetic et al., 2002). Much less information is available on the biological role of leptin in birds (see reviews: McMurtry et al., 2001; Taouis et al., 2001). Beyond its effect on feed intake in the chicken (Raver et al., 1998; Denbow et al., 2000; Dridi et al., 2000) and a wild bird species (Lohmus et al., 2003), and a role in embryogenesis (Ribatti et al., 2001; Macajova et al., 2002), very little is known about the physiological role of leptin in domestic birds. Much more has been reported on the developmental patterns of leptin gene expression (Ashwell et al., 2001), and influences of other hormones and nutrients on leptin gene expression levels (Ashwell et al., 1999a,b; Taouis et al., 2001).

\footnotetext{
8623.

* Corresponding author. Tel.: +1-301-504-8803; fax: +1-301-504E-mail address: mcmurtry@anri.barc.usda.gov (J.P. McMurtry).
}

To understand the physiological significance of a hormone, it is important to determine its possible interaction with other circulating proteins and its bioavailability to target tissues. To address this issue, we conducted a series of experiments to determine target tissues for leptin in the chicken, and to assess both in vivo and in vitro, whether leptin binding proteins are present in chicken plasma.

\section{Materials and methods}

\subsection{Animals}

The chicken experiment was conducted with a research protocol approved by the Beltsville Agricultural Animal Use and Care Committee and the U.S. Department of Agriculture Radiation Safety Committee. Day-old male broiler chicks were purchased from Shaver Poultry Breeding Farms, Cambridge, ON, Canada, and grown in brooder batteries until 3 weeks of age. A standard commercial starter diet $(22 \% \mathrm{CP} ; 3150 \mathrm{kcal} / \mathrm{kg} \mathrm{ME})$ and water were available ad libitum. At 3 weeks of age, the birds were transferred to 
individual sampling cages for acclimatization, and provided a grower diet $(20 \% \mathrm{CP} ; 3150 \mathrm{kcal} / \mathrm{kg} \mathrm{ME})$ and water ad libitum. One week later (1.8-2.0 kg body mass), a cannula was surgically inserted in the jugular vein of each bird as previously described (McMurtry and Brocht, 1984). The clearance and uptake study was conducted 3 days after surgery. During the 3-day post-operative period, feed intake ( $85 \mathrm{~g} /$ day) and body mass were monitored daily. Cannulated birds, which did not eat or lost body mass, were not included in the infusion study.

\subsection{Clearance and plasma distribution of radiolabeled leptin}

A blood sample was drawn from each cannulated bird prior to infusion of radiolabeled hormone (time 0). Mouse and chicken leptin share a high degree of structural similarities (Taouis et al., 2001; Doyon et al., 2001). Mouse leptin has been shown to be biologically active in the chicken (Lamosova and Zeman, 2001; Lamosova et al., 2003). Due to the structural homology between chicken and mouse leptin, and the bioactivity of mouse leptin in the chicken, mouse leptin was used in this study. Radiolabeled ${ }^{125}$ I-mouse leptin $(135 \mu \mathrm{Ci} / \mu \mathrm{g})$ was purchased from Linco Research (St. Charles, MO USA), and infused via the cannula at a concentration of $40 \mu \mathrm{Ci} / \mathrm{kg}$ body mass in a volume of $1 \mathrm{ml}$ sterile saline. Blood samples $(1 \mathrm{ml})$ were drawn into EDTA-treated tubes via the cannula at the following times post-infusion: 7.5, 15, 30, 60, 120 and $240 \mathrm{~min}$. The plasma was harvested by centrifugation $(1800 \times g)$, and the radioactivity in a $10-\mu l$ aliquot determined by gamma spectrometry. Trichloroacetic acid (TCA)precipitable radioactivity in each plasma sample was determined by mixing the $10 \mu \mathrm{l}$ aliquot with $1 \mathrm{ml} \mathrm{10 \% (w/v)}$ TCA, followed by centrifugation $(1800 \times g)$, aspiration of the supernatant and counting the precipitate.

The distribution pattern of radiolabeled mouse leptin in plasma was assessed by size-exclusion chromatography. A $250-\mu 1$ plasma sample was extracted with an equal volume of 1,1,2-trichloro-1,2,3-trifluorethane (Freon; AR grade; Mallinckrodt, Paris, KY USA), and $100 \mu \mathrm{l}$ extracted lipidfree plasma was chromatographed on a Superose-12 column (HR 10/30; Amersham Pharmacia Biotech, Piscataway, NJ, USA), equilibrated with a solution containing $50 \mathrm{mM}$ sodium phosphate, $150 \mathrm{mM}$ sodium chloride, $0.02 \%$ sodium azide, and $1 \mathrm{U} / \mathrm{ml}$ heparin at $\mathrm{pH}$ 7.4. The flow rate was 0.5 $\mathrm{ml} / \mathrm{min}$ and $0.5 \mathrm{ml}$ fractions were taken for the measurement of radioactivity. The Superose-12 column was calibrated using the following markers purchased from Amersham Pharmacia Biotech or Sigma, St. Louis, MO, USA: blue dextran, alcohol dehydrogenase $(150 \mathrm{kDa})$, bovine serum albumin (68 kDa), ovalbumin (43 kDa), cytochrome C (12.4 $\mathrm{kDa})$, aprotinin $(6.5 \mathrm{kDa})$, and radiolabeled mouse leptin (16 kDa).

The presence of leptin binding activity was also assessed in vitro. In this procedure, ${ }^{125}$ I-radiolabeled chicken leptin
(200,000 $\mathrm{cpm}$ in $100 \mu \mathrm{l}$ buffer solution) was incubated overnight at $4{ }^{\circ} \mathrm{C}$ with either $200 \mu \mathrm{l}$ male chicken (4 weeks of age) or male turkey (10 weeks of age) plasma. After 24 $\mathrm{h}$ of incubation, the plasma samples $(n=4)$ were subjected to Superose-12 size-exclusion chromatography and evaluated as described above.

\subsection{Tissue uptake and distribution of radiolabeled leptin}

In order to investigate tissue distribution and uptake of radiolabeled mouse leptin, four chickens were killed with sodium pentobarbital at $15 \mathrm{~min}$ and $4 \mathrm{~h}$ post-infusion. Immediately following euthanasia, the birds were exsanguinated and the following tissues were removed and a $1-2 \mathrm{~g}$ sample taken, frozen in liquid nitrogen and counted in a gamma counter: adrenals, brain, breast muscle (pectoralis superficialis), bursa of Fabricius, gizzard, heart, kidney, leg muscle (gastrocnemius), liver, lung, pancreas, small and large intestine, spleen, and testes. TCA-precipitable radioactivity in the tissue samples was determined by homogenizing (Omni tissue pulverizer; Omni International, Waterbury, CT, USA) the samples in $10 \% \mathrm{TCA}(\mathrm{w} / \mathrm{v})$, cooling on ice for $30 \mathrm{~min}$, and centrifuging $(1800 \times g)$ to obtain TCA-soluble and TCA-insoluble fractions. The radioactivity was measured in each sample. Radioactivity in the pellets was determined and the data expressed as TCAprecipitable $\mathrm{cpm} / \mathrm{mg}$ tissue.

\subsection{Ligand blot}

Frozen plasma samples were thawed, and diluted in loading buffer (with or without $5 \mathrm{mM}$ dithiothreitol) and heated to $60{ }^{\circ} \mathrm{C}$ for $5 \mathrm{~min}$, prior to loading the equivalent of $1 \mu \mathrm{l}$ plasma onto $1.5 \mathrm{~mm}, 10 \%$ SDS-polyacrylamide gels. Following electrophoresis, proteins were electroblotted onto $0.2 \mu \mathrm{m}$ nitrocellulose using Tris-glycine buffer $(\mathrm{pH} 8.9$ ) with a semi-dry blotting system (BIORAD, Hercules, CA, USA). Ligand blotting was performed with ${ }^{125}$ I-chicken leptin as previously described for ${ }^{125}$ I-IGF-1 (McMurtry et al., 1996a). Recombinantly derived chicken leptin was kindly provided by A. Parlow (National Hormone and Pituitary Program). Chicken leptin was radiolabeled to a specific activity of $60 \mathrm{Ci} / \mathrm{g}$ using the same procedure as previously reported for chicken IGF-I (McMurtry et al., 1996a). Additionally, one blot from each group was incubated with unlabeled recombinant chicken leptin $(1 \mu \mathrm{g} / \mathrm{ml})$ for $1 \mathrm{~h}$ prior to addition of ${ }^{125}$ I-labeled leptin to determine binding specificity. Blots were exposed to a phosphor imaging screen for $66 \mathrm{~h}$ prior to scanning with a Storm 860 imaging device (AP Biotech, Piscataway, NJ, USA).

\subsection{Statistical analysis}

Tissue uptake data were analyzed by one-way ANOVA with replications, where $p<0.05$ was considered significant. Means were separated by Bonferroni pair-wise tests. Cal- 
culations of leptin metabolic clearance $\left(t_{1 / 2}\right)$ were conducted as previously described (McMurtry et al., 1987).

\section{Results}

\subsection{Tissue distribution of radiolabeled leptin}

To evaluate the transport of radiolabeled leptin from the circulation into tissues, the amount of ${ }^{125}$ I-labeled leptin in tissues at 15 and $240 \mathrm{~min}$ after infusion of the tracer has been expressed as TCA-insoluble radioactivity per mg tissue (Figs. 1 and 2). No correction was made for the plasma content of the different organs or tissues. The amounts of leptin radioactivity per mg wet mass in the various organs or tissues at 15 min post-infusion are presented in rank order of distribution: kidney $>$ testes $>$ lung $>$ spleen $>$ heart $>$ liver $>$ small intestine $>$ large intestine $>$ gizzard $>$ pancreas $>$ bursa $>$ leg muscle $>$ breast muscle $>$ adrenals $>$ brain (Fig. 1). Radioactivity appeared in the kidneys in a greater amount $(p<0.05)$ than in any other tissue. A slightly different distribution of radioactivity was evident at $240 \mathrm{~min}$ post-infusion: lung> kidney $>$ spleen $>$ testes $>$ large intestine $>$ bursa $>$ gizzard $>$ small intestine $>$ heart $>$ liver $>$ pancreas $>$ leg muscle $>$ breast muscle $>$ adrenals $>$ brain (Fig. 2). By 240 min post-infusion, the greatest amount $(p<0.05)$ was associated in the lung. The amount of TCA-precipitable radioactivity in each of the tissues was significantly $(p<0.05)$ less at $240 \mathrm{~min}$ compared to that present at 15 min post-infusion. In general, the pattern of tissue uptake and distribution did not deviate from that presented in Figs. 1 and 2 as cpm per mg wet tissue mass, when TCA-insoluble radioactivity was expressed as a percentage of total counts in individual tissue samples (data not shown).

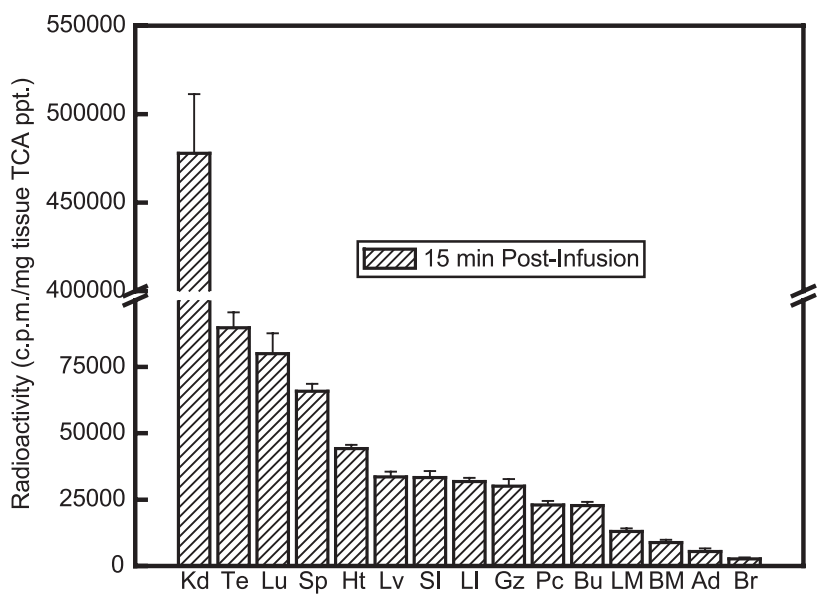

Fig. 1. Radioactivity in chicken organs/tissues (cpm/mg TCA-precipitable) at $15 \mathrm{~min}$ after the administration of radiolabeled mouse leptin. Values are means \pm S.E.M. $(n=4)$. Abbreviations are as follows: $\mathrm{Kd}=$ kidney, $\mathrm{Te}=$ testes, $\mathrm{Lu}=$ lung, $\mathrm{Sp}=$ spleen, $\mathrm{Ht}=$ heart, $\mathrm{Lv}=$ liver, $\mathrm{SI}=$ small intestine, $\mathrm{LI}=$ large intestine, $\mathrm{Gz}=$ gizzard, $\mathrm{Pc}=$ pancreas, $\mathrm{Bu}=$ bursa, $\mathrm{LM}=$ leg muscle, $\mathrm{BM}=$ breast muscle, $\mathrm{Ad}=$ adrenals, $\mathrm{Br}=$ brain, $\mathrm{TCA}=$ trichloroacetic acid.

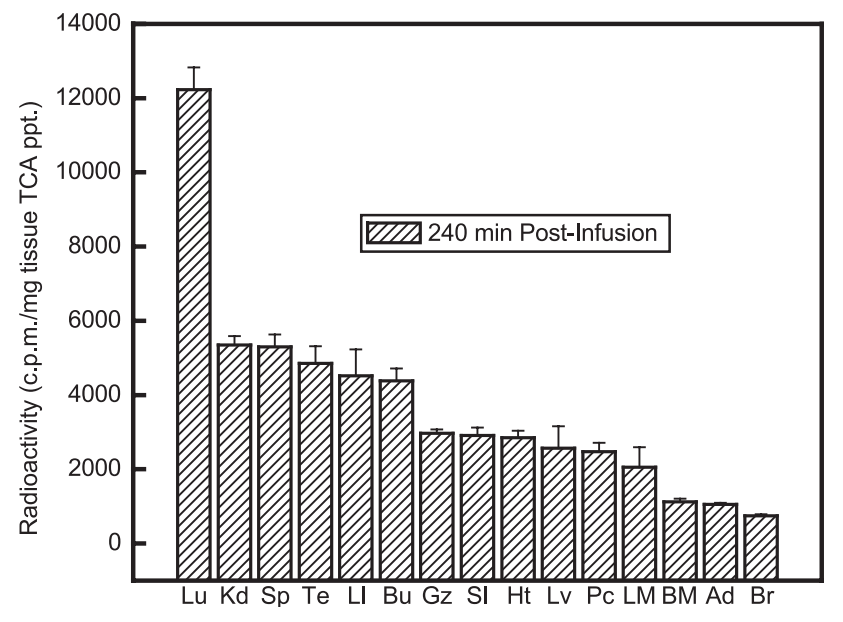

Fig. 2. Radioactivity in chicken organs/tissues (cpm/mg TCA precipitable) at $240 \mathrm{~min}$ after the administration of radiolabeled mouse leptin. Values are means \pm S.E.M. $(n=4)$. Abbreviations are the same as in Fig. 1 .

\subsection{Profiles of leptin radioactivity in plasma}

Chromatography of plasma samples obtained following the in vivo infusion of radiolabeled mouse leptin at neutral $\mathrm{pH}$ on a Superose-12 column produced one peak of radioactivity (Fig. 3). This distribution pattern was the same for all sampling times (7.5 to 240 min post-infusion). A similar distribution pattern of radioactivity was noted following the chromatography of chicken and turkey plasma incubated in vitro with radiolabeled chicken leptin (Fig. 4). In both experiments, the peak in radioactivity occurred at approximately $16 \mathrm{kDa}$. In none of the in vivo samples or in vitro samples chromatographed was there any radioactivity detected which could be ascribed to a higher molecular mass protein. Based on the clearance of radioactivity from plasma, a half-life estimate for leptin was calculated to be $23 \mathrm{~min}$.

\subsection{Ligand blot}

To further assess whether or not leptin-binding proteins are present in circulation, we subjected chicken and turkey plasma to gel electrophoresis ligand blot analysis, and probed the membranes for leptin-binding proteins using ${ }^{125}$ I-chicken leptin. No specific leptin binding activity was noted in any of the avian plasma samples assessed (Fig. 5).

\section{Discussion}

The physiology of leptin has been extensively investigated in the central nervous system for the regulation of feed intake and energy balance. Recently, a growing body of evidence has reported on the actions of leptin in peripheral organs and tissues in mammals. The results of this current study strongly suggest that leptin may have similar peripheral activities in the bird. The chicken leptin receptor cDNA 


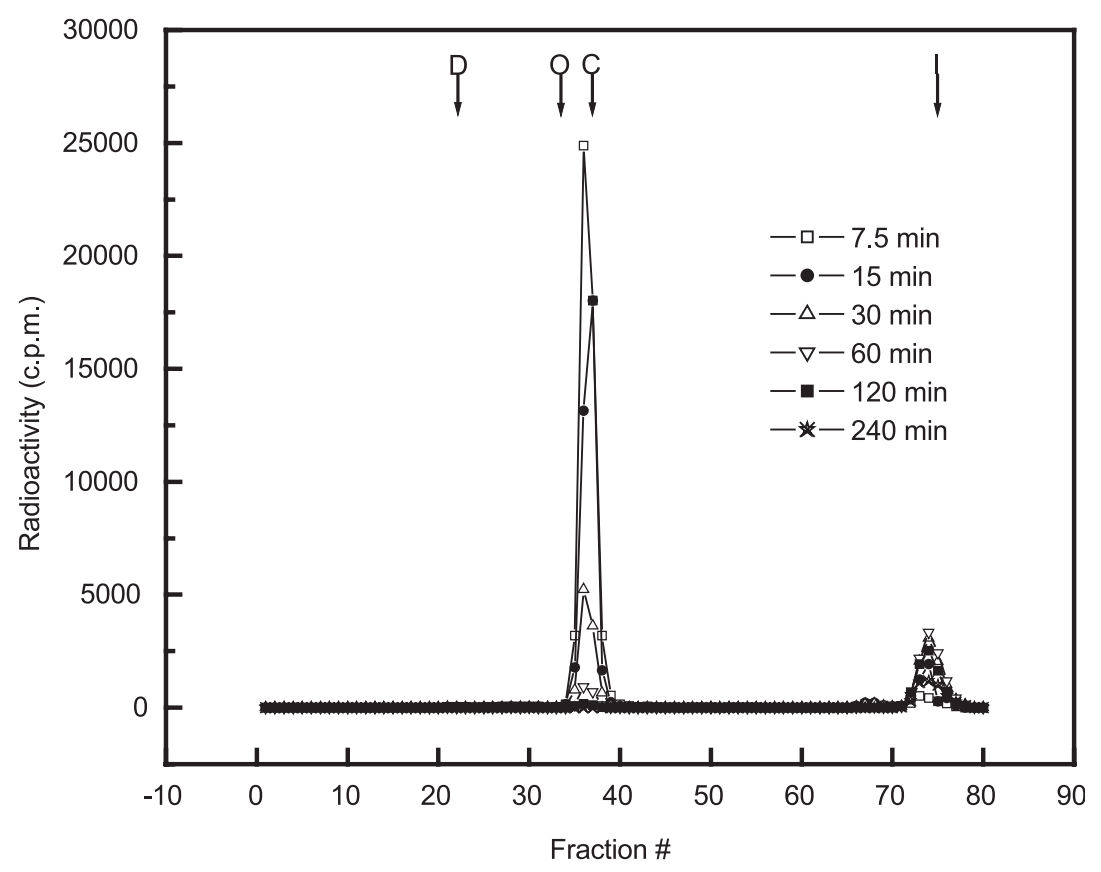

Fig. 3. Superose-12 column neutral chromatography of plasma from chickens following a bolus injection of radiolabeled mouse leptin. Values represent mean values of four birds with a pooled S.E.M. $\pm 21 \mathrm{cpm}$. Chickens were sampled at $7.5 \mathrm{~min}(\mathrm{O}), 15 \mathrm{~min}(\bullet), 30 \mathrm{~min}(\triangle), 60 \mathrm{~min}(\nabla), 120 \mathrm{~min}(\boldsymbol{\square})$, and $240 \mathrm{~min}$ (艾). The positions of molecular mass markers used to calibrate the column are indicated: $\mathrm{D}=$ dextran, $\mathrm{O}=$ ovalbumin, $\mathrm{C}=$ cytochrome $c, \mathrm{I}={ }^{125} \mathrm{I}$.

has been sequenced and characterized. Ohkubo et al. (2000) reported the greatest mRNA expression in the ovary and brain, with less abundance in the liver, kidney and intestine. A similar pattern was observed by Horev et al. (2000) in tissue mRNA expression levels, with the greatest activity in the brain (hypothalamus), followed by lung, kidney, fat, and liver. This pattern is somewhat similar to what we observed in this study in that in general, the greatest radiolabeled

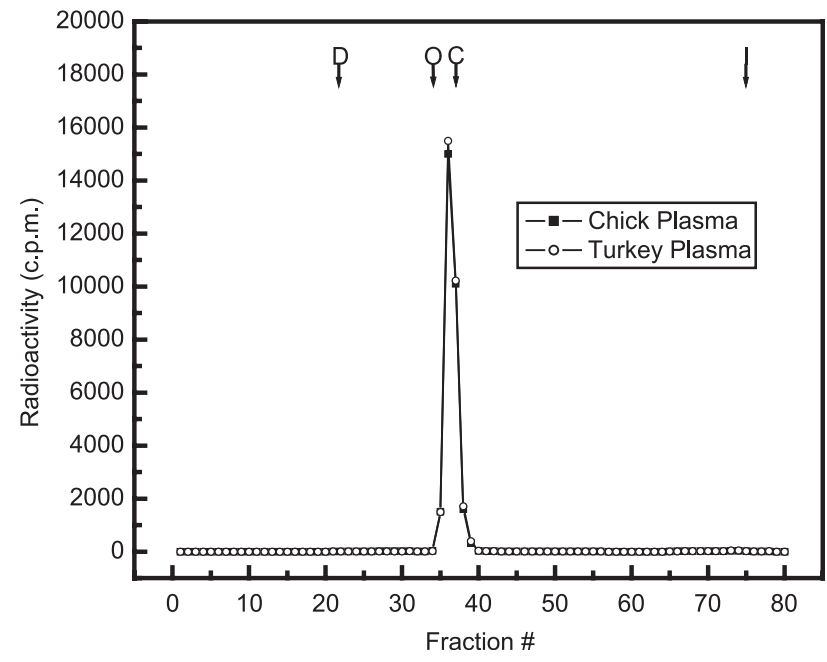

Fig. 4. Superose-12 column neutral chromatography of chicken (ם) or turkey $(\bigcirc)$ plasma incubated in vitro with radiolabeled recombinant chicken leptin. Values represent mean values of four different plasmas with a pooled S.E.M. $\pm 16 \mathrm{cpm}$. The positions of molecular mass markers used to calibrate the column are indicated: $\mathrm{D}=$ dextran, $\mathrm{O}=$ ovalbumin, $\mathrm{C}=$ cytochrome $c, \mathrm{I}={ }^{125} \mathrm{I}$. leptin activity uptake was in the kidney, spleen and lungs, and intestine. Conversely, we found very little radioactivity associated with brain tissue. This may be a difference in sensitivity and assay characteristics, reflecting the fact that measuring gene expression level is able to detect a low abundance of receptor activity, and expression may not be reflective of actual receptor protein levels. It is not surprising that leptin uptake would be high in the kidney, as this tissue has previously been shown to be responsible for leptin clearance (Cumin et al., 1996). A significant amount of radioactivity was also detected in the pancreas. Recently, Benomar et al. (2003) have demonstrated the presence of

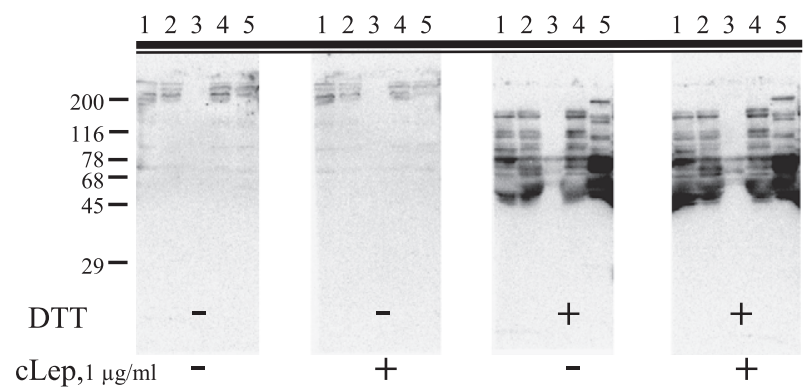

Fig. 5. Ligand blotting of avian plasma samples probed with ${ }^{125} \mathrm{I}-$ recombinant chicken leptin. Samples (Lanes 1 and $4=$ chick plasma, fed; Lane 2 =chick plasma, fasted; Lane 3 =chick embryo plasma; Lane $5=$ turkey plasma) were subjected to gel electrophoresis, blotted and probed with ${ }^{125}$ I-recombinant chicken leptin. Ligand blotting was performed as described in Materials and methods. The molecular mass standards in $5 \mathrm{mM}$ dithiothreitol (Sigma) were: $\beta$-galactosidase (116 $\mathrm{kDa})$, transferrin $(78 \mathrm{kDa})$, BSA $(68 \mathrm{kDa})$, ovalbumin $(43 \mathrm{kDa})$ and carbonic anhydrase $(29 \mathrm{kDa})$. 
the chicken leptin receptor (cOb-R) in isolated chicken islets of Langerhans. Furthermore, the same authors showed that insulin secretion is significantly reduced when the chicken pancreas was perfused with chicken leptin. Beyond these reports, nothing is known on whether leptin has similar functions in chicken tissues as investigated in other species. In mammals, leptin is important for regulating the maturation of fetal lung cells (Bergen et al., 2002), promoting testicular germ cell differentiation and proliferation (El-Hefnawy et al., 2000), enhancing intestinal carbohydrate absorption (Pearson et al., 2001), and for stimulating skeletal muscle thermogenesis (Dulloo et al., 2002). It is noteworthy that in this study, the same tissues (lung, testes, intestine, muscle) contained significant amounts of TCA-precipitable radioactivity. However, only additional investigations can determine whether leptin provokes similar biological responses in the bird.

Various forms of the leptin receptor have been cloned. Six different alternatively spliced isoforms have been reported (Lee et al., 1996). Of these isoforms, only the long form of the leptin receptor (designated Ob-Rb) is capable of mediating the biological actions of leptin. Another isoform, $\mathrm{Ob}-\mathrm{Re}$, is speculated to be a soluble form of the receptor, and may function as a plasma leptin binding protein (Chen et al., 1996). Magni et al. (2000) have reported that the bound/free ratio of plasma leptin is altered in obese individuals with free leptin accounting for $70-80 \%$ of circulating leptin, while in normal subjects only $10-15 \%$ of plasma leptin is unbound.

To date, only the long form of the tissue leptin receptor has been identified in birds (Ohkubo et al., 2000; Horev et al., 2000; Richards et al., 2001). The leptin receptor has also been identified in cells derived from a Leghorn male hepatoma cell line (Cassy et al., 2003). Since apparently the soluble short form is not present in avian plasma, this may, in part, explain our observation of the absence of a circulating leptin binding protein in chick plasma. Multiple experimental approaches were used to demonstrate that a majority, if not all of the leptin in chick blood circulates in the free form.

The calculated mean plasma half-life of leptin in this study was $23 \mathrm{~min}$, which is similar to the half-life estimate of $25 \mathrm{~min}$ in humans (Klein et al., 1996). A somewhat longer half-life estimate for leptin of 96.4 and $49.5 \mathrm{~min}$ for the rhesus monkey and mouse, respectively, has been reported (Ahren et al., 2000). Overall, the half-lives and clearance rates of peptide and protein hormones in birds appear to be very rapid: insulin $t_{1 / 2}=7-8 \mathrm{~min}$ (McMurtry et al., 1987), glucagon $t_{1 / 2}=4-5$ min (McMurtry et al., 1996b), growth hormone $t_{1 / 2}=13 \mathrm{~min}$ (Proudman and Opel, 1990), insulin-like growth factor-I and -II $t_{1 / 2}=3$ and $5 \mathrm{~min}$, respectively (McMurtry et al., 1996a). This further characterization of leptin behavior in birds contributes additional information regarding the differences and similarities between mammalian and avian systems.

\section{Acknowledgements}

The technical support of D. Carbaugh, W. Smoot, and S. Lutz is greatly appreciated. Mention of a trade name, proprietary product, or specific equipment does not constitute a guarantee or warranty by the U.S. Department of Agriculture and does not imply its approval to the exclusion of other suitable products.

\section{References}

Ahren, B., Baldwin, R.M., Havel, P.J., 2000. Pharmacokinetics of human leptin in mice and rhesus monkeys. Int. J. Obes. 24, 1579-1585.

Ashwell, C.M., Czerwinski, S.M., Brocht, D.M., McMurtry, J.P., 1999a. Hormonal regulation of leptin expression in broiler chickens. Am. J. Physiol. 276, R226-R232.

Ashwell, C.M., McMurtry, J.P., Wang, X.H., Zhour, Y., VasilatosYounken, R., 1999b. Effects of growth hormone and pair-feeding on leptin mRNA expression in liver and adipose tissue. Domest. Anim. Endocrinol. 17, 77-84.

Ashwell, C.M., Richards, M.P., McMurtry, J.P., 2001. The ontogeny of leptin mRNA expression in growing broilers and its relationship to metabolic body weight. Domest. Anim. Endocrinol. 21, 161-168.

Attele, A.S., Shi, Z.Q., Yuan, C.S., 2002. Leptin, gut, and food intake. Biochem. Pharmacol. 63, 1579-1583.

Barb, C.R., Hausman, G.J., Houseknecht, K.L., 2001. Biology of leptin in the pig. Domest. Anim. Endocrinol. 21, 297-317.

Benomar, V., Rideau, N., Crochet, S., Derouet, M., Taouis, M., 2003. Leptin fully suppresses acethylcholine-induced insulin secretion and is reversed by tolbutamide in isolated perfused chicken pancreas. Horm. Metab. Res. 35, 81-85.

Bergen, H.T., Cherlet, T.C., Manuel, P., Scott, J.E., 2002. Identification of leptin receptors in lung and isolated fetal type II cells. Am. J. Respir. Cell Mol. Biol. 27, 71-77.

Blevins, J.E., Schwartz, M.W., Baskin, D.G., 2002. Peptide signals regulating food intake and energy homeostasis. Can. J. Physiol. Pharma. 80, $396-406$.

Cassy, S., Derouet, M., Crochet, S., Dridi, S., Taouis, M., 2003. Leptin and insulin downregulate leptin receptor gene expression in chicken-derived Leghorn male he patoma cells. Poult. Sci. 82, 1573-1579.

Chen, H., Charlat, O., Tartaglia, L.A., Woolf, E.A., Weng, X., Ellis, S.J., Lakey, N.D., Culpepper, J., Moore, K.J., Breitbart, R.E., Duyk, G.M., Tepper, R.I., Morgenstern, J.P., 1996. Evidence that the diabetes gene encodes the leptin receptor: identification of a mutation in the leptin receptor gene in $\mathrm{db} / \mathrm{db}$ mice. Cell 84, 491-495.

Chilliard, Y., Bonnet, M., Delavaud, C., Faulconnier, Y., Leroux, C., Djiane, J., Bocquier, F., 2001. Leptin in ruminants. Gene expression in adipose tissue and mammary gland, and regulation of plasma concentration. Domest. Anim. Endocrinol. 21, 271-295.

Cumin, F., Baum, H.-P., Levens, N., 1996. Leptin is cleared from the circulation primarily by the kidney. Int. J. Obes. 20, 1120-1126.

Denbow, D.M., Meade, S., Robertson, A., McMurtry, J.P., Richards, M., Ashwell, C., 2000. Leptin-induced decrease in food intake in chickens. Physiol. Behav. 69, 359-362.

Doyon, C., Drouin, G., Trudeau, V.L., Moon, T.W., 2001. Molecular evolution of leptin. Gen. Comp. Endocrinol. 124, 188-198.

Dridi, S., Raver, N., Gussakovsky, E.E., Derouet, M., Picard, M., Gertler, A., Taouis, M., 2000. Biological activities of recombinant chicken leptin C4S analog compared with unmodified leptins. Am. J. Physiol. 279, E116-E123.

Dulloo, A.G., Stock, M.J., Solinas, G., Boss, O., Montani, J.P., Seydoux, J., 2002. Leptin directly stimulates thermogenesis in skeletal muscle. FEBS Lett. 515, 109-113. 
El-Hefnawy, T., Ioffe, S., Dym, M., 2000. Expression of the leptin receptor during germ cell development in the mouse testis. Endocrinology 141, $2624-2630$.

Horev, G., Einat, P., Aharoni, T., Eshdat, Y., Friedman-Einat, M., 2000. Molecular cloning and properties of the chicken leptin-receptor (CLEPR) gene. Mol. Cell. Endocrinol. 162, 95-106.

Klein, S., Coppack, S.W., Mohamed-Ali, V., Landt, M., 1996. Adipose tissue leptin production and plasma leptin kinetics in humans. Diabetes 45, 984-987.

Lamosova, D., Zeman, M., 2001. Effect of leptin and insulin on chick embryonic muscle cells and hepatocytes. Physiol. Res. 50, 183-189.

Lamosova, D., Macajova, M., Zeman, M., Mozes, S., Jezova, D., 2003. Effect of in novo leptin administration on the development of Japanese quail. Physiol. Res. (Prague) 52, 201-209.

Lee, G.H., Proenca, R., Montez, J.M., Carroll, K.M., Darvishzadeh, J.G., Lee, J.I., Friedman, J.M., 1996. Abnormal splicing of the leptin receptor in diabetic mice. Nature 379, 632-635.

Lohmus, M., Sundstrom, L.F., El Halawani, M., Silverin, B., 2003. Leptin depresses food intake in great tits (Parus major). Gen. Comp. Endocrinol. 13, 57-61.

Macajova, M., Lamosova, D., Zeman, M., 2002. Role of leptin in Japanese quail development. Acta Vet. Brno 71, 473-479.

Magni, P., Motta, M., Martini, L., 2000. Leptin: a possible link between food intake, energy expenditure, and reproductive function. Regul. Pept. 92, 51-56.

Margetic, S., Gazzola, C., Pegg, G.G., Hill, R.A., 2002. Leptin: a review of its peripheral actions and interactions. Int. J. Obes. Relat. Metab. Disord. 26, 1407-1433.

McMurtry, J.P., Brocht, D.M., 1984. A surgical technique for serial blood sampling or continuous infusion of adult turkey hens. Poult. Sci. 63, $1661-1663$.

McMurtry, J.P., Rosebrough, R.W., Steele, N.C., 1987. Insulin metabolism and its effect on blood electrolytes and glucose in the turkey hen. Poult. Sci. 86, 309-313.
McMurtry, J.P., Francis, G.L., Upton, Z., Walton, P.E., Rosselot, G., Caperna, T.J., Brocht, D.M., 1996a. Plasma clearance and tissue distribution of labelled chicken and human IGF-I and IGF-II in the chicken. J. Endocrinol. 150, 149-160.

McMurtry, J.P., Tsark, W., Cogburn, L., Rosebrough, R., Brocht, D., 1996b. Metabolic responses of the turkey hen (Meleagris gallopavo) to an intravenous injection of chicken or porcine glucagon. Comp. Biochem. Physiol., C 114, 159-163.

McMurtry, J.P., Ashwell, C., Richards, M., Vasilatos-Younken, R., 2001. Leptin: molecular biology and physiology. In: Dawson, A., Chaturvedi, C.M. (Eds.), Avian Endocrinology. Narosa Publishing House, New Delhi, India, pp. 317-328.

Ohkubo, T., Tanaka, M., Nakashima, K., 2000. Structure and tissue distribution of chicken leptin receptor (cOb-R) mRNA. Biochim. Biophys. Acta 1491, 303-308.

Pearson, P.Y., O'Connor, D.M., Schwartz, M.Z., 2001. Novel effect of leptin on small intestine adaptation. J. Surg. Res. 97, 192-195.

Proudman, J.A., Opel, H., 1990. Half-life and metabolic clearance rate of recombinant-derived chicken growth hormone and purified turkey growth hormone in intact and hypophysectomized turkeys. Poult. Sci. $69,1569-1575$.

Raver, N., Taouis, M., Dridi, S., Derouet, M., Simon, J., Robinzon, B., Djiane, J., Gertler, A., 1998. Large-scale preparation of biologically active recombinant chicken obese protein (leptin). Protein Expr. Purif. 14, 403-408.

Ribatti, D., Nico, B., Belloni, A.S., Vacca, A., Roncali, L., Nussdorfer, G.G., 2001. Angiogenic activity of leptin in the chick embryo chorioallantoic membrane is in part mediated by endogenous fibroblast growth factor-2. Int. J. Mol. Med. 8, 265-268.

Richards, M., Poch, S.M., Ashwell, C.M., 2001. Identification and expression of the turkey leptin receptor gene. Poult. Sci. 80 (Suppl. 1), 394.

Taouis, M., Dridi, S., Cassy, S., Benomar, Y., Raver, N., Rideau, N., Picard, M., Williams, J., Gertler, A., 2001. Chicken leptin: properties and actions. Domest. Anim. Endocrinol. 21, 319-327. 